amples of what they have taught with success. I suspect those examples will involve classic speeches and writings and the most significant events in American political history, e.g., the Revolution, the framing and ratifying of the Constitution, the Civil War, the Civil Rights Movement. In addition, some examples should come from political history generally, such as the French Revolution and the World Wars.

Any general treatment of the concepts of government should be illustrated by specific examples. If that is done, we will discover that Americans agree more on matters of procedure, such as the rule of law, than they agree on substance, but that even where they disagree, they tend to frame their arguments in terms of rights. Both the procedures associated with the rule of law and the concept of individual rights say a lot about American politics, or, as some would say, American political culture.

\section{Reference}

Center for Civic Education. 1994. National Standards for Civics and Government. Calabasas, CA: Center for Civic Education.

\begin{abstract}
About the Author
Murray Dry is Charles A. Dana Professor and chair of the Department of Political Science at Middlebury College. He teaches courses in political philosophy, American political thought, and American constitutional law, and he is working on a book on freedom of speech in political philosophy and American constitutional law. He has published articles on this subject in Constitutional Commentary and The Supreme Court Review.
\end{abstract}

\title{
Symbols as Substance in National Civics Standards
}

\author{
Richard M. Merelman, University of Wisconsin
}

In the first chapter of his pathbreaking The Making of Citizens Charles Merriam observed, “. . . every modern state develops a farreaching program designed to maintain the morale of its constituent members at a point where their activities will fit in with and perform the functional activities necessary for group survival"' $(1931,13)$.

At approximately the same period the Italian Marxist Antonio Gramsci wrote from a Fascist prison cell, ". . . every state is ethical inasmuch as one of its most important functions is to raise the great mass of the population to a particular cultural and moral level. . . which corresponds to the needs of the productive forces for development, and hence to the interests of the ruling classes" (Hoare 1971, 258).

Though two writers more politically opposed than Gramsci and Merriam would be hard to imagine, both agreed that the school played a vital role in this process of sustaining the state politically. Merriam put it this way: "With the development of universal and compulsory education covering a considerable span of life, the importance of this institution for the purpose of fostering group solidarity becomes increasingly evident" $(1931,17)$. This observation resembles Gramsci's: "The school as a positive education function is one of the most important State activities in this sense" (Hoare 1971, 258).

Despite these prognostications, American public schools have long resisted national control over such features of political education as textbook and curricular content, teaching certification, student selection, and performance criteria. Indeed, the legislation that established the U.S. Department of Education in 1979 stipulated that the department must not establish a national curriculum. And the recently enacted Goals 2000: Educate America Act of 1993 only sets up a mechanism for creating voluntary national education standards.

But even voluntary national standards and assessments in civics represent a potentially significant centralization of American political education, following the direction Gramsci and Merriam would have predicted. What is the significance of this belated development? What accounts for the recent movement towards national educational stan- dards in civics? What consequences will flow from the new national civics standards and performance assessments?

To answer these questions, consider four different models of civics in political education. In terms reminiscent of Gramsci, Pamela Conover outlines the first modelcivics as a means of supporting a system of unequal political power. Conover writes, "Socialization is ... a process used by those who rule to reinforce their rule" (1991, 135). From this perspective, national standards in civics can best be understood as serving the interests of American political elites. Following Gramsci, let us call this the hegemonic model of civics education.

A different model is that of civics promoting public control over the powerful. In its 1971 call for improvements in civics education, the American Political Science Association Committee on Pre-Collegiate Education advocated precisely this form of political education:

While schools should not be a birth place of cynicism or despair about the political life of the society, neither should they communicate to 
students highly unrealistic and romanticized images of human politics. The existence of conflict, the importance of self-interest, the failures of public policies and political institutions to achieve given objectives, and inequalities in the distribution of political power are examples of political realities which most students readily learn about from one source or another. Schools should provide a learning environment in which students can develop a cognitive understanding of the realities of political life (Committee on Pre-Collegiate Education, 434).

This is a critical model of civics. Merriam outlined a third model, imagining a "struggle . ... in the development of civic training . . . between the older system of traditional indoctrination, and one in which much greater stress is laid upon the element of invention, adaptability, and adjustment in a changing world" (301). This model blends criticism and hegemony into a transformative model of civics education.

Finally, the development of national standards in civics may less influence its supposed targetsstudents-than educational policymakers themselves. Perhaps the creation of national civics standards and assessments is a ritual of political nostalgia, creating for policymakers the illusion that genuine progress in political education has at long last begun, and will strengthen the weakening hold of politics on the young. The relevant anthropological illustration is the ghost dance of Plains Indians, a dramatic invocation of powerful tribal spirits to defy the reality of extinction at the hands of whites. National civics standards may reassure political elites that "something is being done" to meet a "crisis" in citizenship. Let us call this the symbolic model of national standards.

To which of these models do national civics standards and assessments belong? Let me turn to the standards themselves for illumination. According to the Center for Civic Education, which created the proposed K-12 civics standards, published in November 1994, "the goal of education in civics and government is informed, responsible participation in political life by competent citizens committed to the fundamental values and principles of American constitutional democracy" (1).

Unfortunately, this programmatic statement doesn't help us much, for it may support any of the four models of civics education. However, choosing "participation" and "fundamental values" as central foci does at least give us some insight into the thinking of those responsible for the reform; clearly, the long-term decline in conventional political participation among

\section{Perhaps the creation of national civics standards and assessments is a ritual of political nostalgia, creating for policymakers the illusion} that genuine progress in political education has at long last begun, and will strengthen the weakening hold of politics on the

young.

Americans weighs heavily upon those designing the standards. But what exactly is threatened by this decline-the hegemony of leaders, the power of ordinary citizens, the transformative capacity of the polity, or the Weltanschauung of educational policymakers?

To address this question, let me concentrate on that section of the proposed performance standards for high schoolers which is devoted to American political culture. I choose this section because participation and fundamental democratic principles figure prominently in most discussions of American political culture. More important, national civics standards are an effort to reshape American political culture. Finally, as it turns out, the section on political culture takes us a long step towards answering the questions I've posed.

In its first paragraph, which offers a summary and rationale for its "what is American political culture?" section, the Center writes:

In contrast to most other nations, the identity of an American citizen is defined by shared political values and principles rather than by ethnicity, race, religion, class, language, gender, or national origin. These shared values and principles have helped to promote cohesion in the daily life of Americans and in times of crisis have enabled them to find common ground with those who differ from them (103).

Conceptually, the first sentence of this paragraph raises many questions. For example, if a Russian "shares" the political values and principles of an American, has the Russian an American identity? Probably not, but the sentence seems to allow it. More important, what about the American citizen who does not share "American" political values and principles, such as the Christian Fundamentalist who puts God above the Constitution, or the 1960's Weathermen, who placed revolution above the law? Are these people not Americans? This statement verges perilously close to establishing an ideological test to compete with the legal definition of American citizenship.

And what of the many Americans who share some political values but not others? What about the few who embrace civil liberties, but reject racial equality; or the many who choose minority rights over majority rule? Do these people lack an American identity? Indeed, what are these American values anyway, and what is the operational definition of their being "shared?" How large a proportion of Americans must embrace American values before they become shared? $75 \%$ ? $60 \%$ ?

Now consider the second sentence of the paragraph, which argues that the function of American political culture is "to promote cohesion in the daily life of Americans and in times of crisis ... to find common ground with those who differ from them." No one really believes that American politi- 
cal values play much of a conscious role in regulating ordinary daily life among Americans. And to whom does the word "those" refer? Surely not other Americans, for the sentence restricts the term "Americans" to those who share values. Perhaps "those" refers to non-Americans, but how can American values promote "common ground" with those who reject American values? Yet if neither Americans nor non-Americans are "those who differ," there isn't anyone left. Shared values cannot then deal with the political crises to which the sentence refers.

Interestingly, the word "participation" does not appear in the entire section on American political culture. In fact, the only examples of participation suggested in the political culture section are forms of political conflict (e.g., labor disputes, race riots), which, "with notable exceptions," in America have "generally been less divisive than in many other nations" (104). Yet, as we have seen, the standards identify enhanced participation as a central goal of civics.

But if political participation isn't part of American political culture, yet constitutes a rationale for civics standards, is the Center attempting to insert participation within the culture it otherwise so fulsomely praises? And if participation emerges only as conflict, why should we want more participation? Finally, what happened to participation in support of liberal democratic principles? Apparently, when push comes to shove, the Center believes that American political culture ought to, and does in fact, subordinate participation to the shared political values and principles of liberal democracy.

The Center extends its emphasis on liberal democratic principles to the evaluation of students. It states that, "students should be able to explain the importance of shared political and civic beliefs and values to the maintenance of constitutional democracy in an increasingly diverse American society" (103).

Were students able to meet this standard, they would be considerably in advance of their teachers. Political scientists differ sharply on precisely what, if any, role shared political beliefs play in the United States. Some argue that shared beliefs simply rationalize political and economic inequalities; others argue that shared beliefs exist, but are at best too weak to regulate behavior; and yet others agree with the Center that shared beliefs do help maintain American democracy (for a review, see Jackman 1994). Yet despite this long-standing scholarly disagreement, students are to accept only the third position.

How does the Center identify the

... the proposed civics

standards emphasize shared political values over political participation; oversimplify the relationships between American political values; assert a highly contestable function (cohesion) for shared values; and rely mainly upon elite statements to identify these political values.

shared beliefs of Americans? The section on political culture refers us to basic documents in American history, ranging from the Declaration of Independence to Martin Luther King Jr.'s "'Letter from a Birmingham Jail." No one would deny that these documents contain important American political values, but how do they square with the beliefs of ordinary Americans? Should the values of political leaders be taken as typical of most American citizens?

The proposed standards do name some of the values in American political culture; however, these too are open to debate. Is it really true, as claimed, that Americans hold "high expectations of what elected officials and government should do" (104)? The claim is so vague as to defy confirmation or refutation. Are Americans really so willing "to admit to faults or shortcomings in their society" (104)? One can almost hear the chuckles from foreigners who resent Americans boasting about the superiority of life in the United States. Do Americans really believe "that they can individually and through collective effort alleviate social, economic or political problems" (104)? If this claim is true, it seems to have escaped many contemporary pollsters, who report much public pessimism about the American future.

To sum up: judging by the section on political culture, the proposed national civics standards emphasize shared political values over political participation; oversimplify the relationships between American political values; assert a highly contestable function (cohesion) for shared values; and rely mainly upon elite statements to identify these political values. Of the four models of political education described earlier, the section on political culture most fits the hegemonic model; it is the powerful who would benefit most from the paucity of criticism and political participation which the proposed standards encourage; from the rhetorical silences about the actual extent of value sharing, the assumed consistency of values, and the cohesive function of shared values; from the heavy reliance on seminal public documents to define values; and from the implicit exclusion of those who do not espouse these values from being, in some sense, "American."

Elsewhere in the proposed standards, the Center pays attention to group organization, a topic that opens the way for a less hegemonic picture of American politics. But in these considerations the Center never questions the fundamental soundness of the status quo. For example, the standards classify associations as religious, service, civic, interest, labor, and professional. Nowhere in this classification is there a separate niche for protest organizations, nor for the 
powerful mass movements they support.

Meanwhile, in its political culture section, the Center discusses political conflict, another potentially counter-hegemonic topic. But the Center asks students to "explain ... why political conflict in the United States, with notable exceptions such as the Civil War, nineteenth-century labor unrest, the civil rights struggles of $1950 \mathrm{~s}$ and 1960 s and the opposition to the war in Vietnam, has generally been less divisive than in many other nations"' (104). However, if one adds to this list the Catholic-Protestant struggles of the mid-nineteenth century, the outburst of nativism at the turn of the twentieth century, the often-violent unionization struggles of the 1930s, and the Red Scare of the $1920 \mathrm{~s}$, these divisive "exceptions" come perilously close to becoming the "rule" of American politics, a rule the standards rhetorically obscure.

What explains the hegemonic tenor of the proposed national civics standards and assessments? Partly the answer is circumstantial; the unprecedented legislative mandate for national educational standards simply allows those long desirous of improving civics the opportunity to act. But this fact does not explain why a hegemonic model should be the approach of choice, and why this model should have become part of the contemporary civics reform movement.

A tempting speculation is that recent culture wars involving race, religion, gender, and multiculturalism have spurred the development of hegemonic civics standards. Indeed, immediately preceding the political culture section in the proposed standards is a section devoted to "diversity in American society" (103). Although the proposed standards never actually define diversity, the term's proximity to the section on American political culture at least suggests an implicit narrative connection between the two subjects.

The nature of this connection appears in the proposed content standard regarding diversity. Students should be able to "explain the importance of adhering to con- stitutional values and principles in managing conflicts over diversity", (103). Diversity apparently creates conflicts which threaten the constitutional principles of American political culture; when such conflicts occur, the proposed standards recommend that diversity give way. Is it too great a stretch to suggest that these conflicts have contributed to the emergence of hegemonic standards? Perhaps hegemonic civics standards are a response to conflicts over diversity in America.

Yet this interpretation is premature. For one thing, the proposed

... these factors lead me to conclude that the proposed national civics standards are mainly a symbolic ritual masked as an educational policy for reinforcing cultural hegemony.

standards do not entirely exclude the critical model of civics. To the contrary, students are required to "evaluate, take, and defend positions." There is always the possibility some students might take positions that are at odds with the American political culture the proposed standards describe.

Moreover, one would expect seriously hegemonic standards to have a greater prospect of success. The proposed standards are only voluntary, and the actual uses to which performance on national assessments will be put remain unclear. So far, meeting the new standards has no tangible payoffs for students or schools.

In addition, parallel to the development of national standards and assessments, the new law requires policymakers eventually to create "opportunity to learn" standards. "Opportunity to learn" will require schools to give all students fair opportunities to attain the new content standards. In its effort to pro- vide equity between advantaged and disadvantaged students, opportunity to learn may ultimately inhibit implementing any national standards at all. Indeed, it may open the way to a flood of lawsuits that will tie up national standards indefinitely. No wonder supporters of high stakes performance standards, such as Diane Ravitch and Albert Shanker, fought hard against opportunity to learn provisions (Ravitch 1995, 150-53).

Moreover, the process of developing and implementing national standards seems likely to become a bureaucratic nightmare. Two newly mandated bodies-the National Education Goals Panel and the National Education Standards and Improvement Council-divide between them uncertain and potentially conflicting jurisdictions over the standards. The new legislation includes little money for promoting the standards in schools, for training teachers, or even for developing new performance assessments.

Even if the money appears, what about the time devoted to civics in school? Currently the typical K-12 sequence allocates far too little civics instructional time to meet the proposed new goals. And schools won't take time away from other subjects, most of which are now also embroiled in national standard setting, and have their own claims to curricular attention (American Journal of Education 1994, 383-580).

Taken as a whole, these factors lead me to conclude that the proposed national civics standards are mainly a symbolic ritual masked as an educational policy for reinforcing cultural hegemony. Political rituals typically act out the many conflicts and ambivalences in a political culture. In the case of the proposed national civics standards, "shared values" collide with "diversity;" "merit" (in the form of high performance on assessments) encounters "equality" (in the form of opportunity to learn standards); freedom (in the form of voluntary standards) encounters constraint (in the desire for greater school accountability); and expertise (in the form of more reliable performance assessments) encounters democ- 
racy (in improved civic education for every student).

These polarities in the proposed standards no doubt reflect the multiple constituencies of American education, and the consequent pluralism and compromise of educational policy making. But because they are also symbolic, national standards and assessments in civics will allow policymakers to surmount pluralism, to reproduce these polarities, and to join hands in a ritualized dance of hegemonic public policy. The performance may satisfy policymakers that civics education will reduce contemporary strife, but I think what is happening is happening mainly to the performers themselves, not to their putative student audience.

\section{References}

American Journal of Education. "Educational Reform through National Standards and Assessment." 1994. 102 (4), 383-580.

Center for Civic Education. 1994. National Standards for Civics and Government. Calabasas, CA: Center for Civic Education.

Committee on Pre-Collegiate Education, American Political Science Association. 1971. "Political Education in the Public Schools: The Challenge for Political Science," PS 4: 432-58.

Conover, Pamela. 1991. "Political Socialization: Where's the Politics?" in Political Science: Looking to the Future, vol. 3, ed. William Crotty. Evanston, IL: Northwestern University Press.

Hoare, Quentin, and Geoffrey Nowell Smith, eds. 1971. Selections from the Prison Notebooks of Antonio Gramsci. New York: International Publishers.

Jackman, Mary R. 1994. The Velvet Glove: Paternalism and Conflict in Gender, Class, and Race Relations. Berkeley and
Los Angeles: University of California Press.

Merriam, Charles. 1931. The Making of Citizens: A Comparative Study of Methods of Civic Training. Chicago: University of Chicago Press.

Ravitch, Diane. 1995. National Standards in American Education: A Citizen's Guide. Washington: The Brookings Institution.

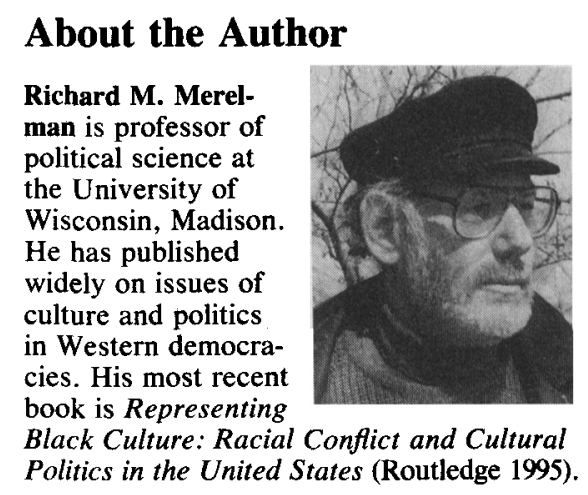

\title{
Civics Is Not Enough: Teaching Barbarics in K-12*
}

\author{
John R. Hibbing and Elizabeth Theiss-Morse, University of Nebraska
}

Like most college-level teachers of political science, we have been known to complain about the knowledge level of students who enter our classrooms. These students, who have already had at least 12 years of schooling, sometimes lack the most rudimentary background information. One of us recently administered a beginningof-the-semester quiz in an Introduction to American Government class to determine the students' pre-existing level of political information. The results were dismal.

Only $5 \%$ of the class knew that John Major was the Prime Minister of Great Britain; just 5\% knew that William Rehnquist was Chief Justice of the United States Supreme Court; $10 \%$ could correctly identify the Speaker of the House of Representatives; $10 \%$ knew the correct length of a term for U.S. Senators and for U.S. Representatives; $24 \%$ knew there were nine justices on the Supreme Court; and $13 \%$ of the class did not know that Al Gore was vice-president of the United
States. Skills in tracking down information, critical thinking, and expression, alas, are typically not much better than students' knowledge base.

Although the above-mentioned deficiencies are indeed serious, another problem exists that we believe is more serious. Unlike knowledge and skill failings, it has not been accorded any attention from educators. Fortunately, it is a problem that can be addressed if needed changes in the curriculum and in teaching techniques in K-12 civics and government education are adopted. We need to shift the emphasis in teaching college-level political science classes as well.

\section{The Messiness of Democratic Processes}

$\mathrm{K}-12$ civics education gives too much attention to our government's clean constitutional components and arrangements and too little attention to the natural give and take (and sometimes rough and tumble) that inevitably occurs when large numbers of diverse people are allowed and even encouraged to get involved in government. If the public is divided on the proper solutions to society's problems (and the American public is) and if democracy involves working through these differences in an open manner (it does), the resultant process can be nothing other than slow and unruly and perforce will involve debate and compromise. Yet, these simple points have not been impressed upon the psyches of most residents of the United States.

Using intensive focus-group sessions and a specially designed national survey of more than 1,400 individuals administered in 1992, we recently completed a major project on public attitudes toward Congress and other elements of the political system (Hibbing and Theiss-Morse 1995). We were not surprised to find a public upset by specific events such as the congressional pay raise, the check-kiting 